\title{
The Performance of Student Fighting Spirit in Football Learning
}

\author{
Zalfendi $^{1 *}$, Emral $^{1}$ \\ ${ }^{1}$ Faculty of Sport Science; Universitas Negeri Padang, Indonesia \\ *Corresponding author. Email: zalfendi@yahoo.co.id
}

\begin{abstract}
The problem in this research is still not satisfied student result in football learning. It is caused by various factors including learning model which is used by teachers. So, it is necessary to develop different football learning model from conventional model that is learning model based on Fighting Spirit. This type of research is a development research aimed at obtaining learning development model based on Fighting Spirit on football sports in college. Subjects in this research are students of Sport Faculty in Padang State University, lecturer of Sport Faculty in Padang State University, and football expert. Development of learning model procedure by adopting the ADDIE model which consists of five stages, that is analysis, design, development, implementation, and evaluation. In order to measure the feasibility of model in this research using two data analysis technique that is by quantitative method using rating scale and by qualitative method using observational persistence and triangulation. Based on result needs analysis of football learning model development found that the student's Fighting Spirit is still low in learning football. So it needs a Fighting Spirit learning model to increase the spirit and potential within the student self. If their Fighting Spirit is high, the football learning result will achieve desired expectation.
\end{abstract}

\section{Keywords: Football Learning Model, Fighting Spirit}

\section{INTRODUCTION}

Football is a sport and a very popular team game today, it prove by almost a whole world played this sport. The idea in football is to create a lot of goals and keep the goals from conceding. Football is a group game involving many elements such as physical, technical, tactical, and mental [1]. Football is one of compulsory lesson for Sport Faculty in Padang State University. But, students still get unsatisfied results that almost all lecturers think about how to increase the quality of learning. This is caused by various factor, among them is a learning model where there are still many lecturers using conventional learning model by play and assignment method.

This learning model has a weakness because it optimizes the student's involvement to find and practice the material independently, so the student's ability or potency does not come out. Conventional use also causes students to tend to be individualistic because of the lack of interaction or communication to grow together and share their experiences. Besides that, this also causes student's Fighting Spirit becomes low in learning.

In football, all parts of body can be used, starting from head to head ball, chest to control, foot to kick, and hand is used only for keeper to catch the ball, The foot is the most dominant part of body in football such as to kick, control, stop the ball, run, jump and others.

To be able to increase result in football learning need to be developed an effective and suitable football learning model to increase the ability and achievement of football. This learning model should be directed to the coaching techniques (skills), physical (physical fitness), tactics (mental, memory, intelligence), and also the maturity of the winner.

Physic factor is one of important factor which is often forgotten in learning process. Whereas psychological factors will greatly affect student learning result. Psychology in sport seeks to unite the athlete's soul with their coach, who ultimately makes them an outstanding athlete. "Sport and exercise psychology is the scientific study of people their behavior in sport and exercise context"[2]. This means that sports and psychology are interrelated. The linkage is between athletes and behavior in sports and exercise.

In professional practice, sports psychology is divided into two broad categories that are applied sport psychology and experimental sport psychology [3]. . Applied sport psychology is a practice of psychology that directly relates to athletes or people who take care of sports, such as coaches, managers, and etc. experimental sport psychology is a person who works to examine all things related to sports activities. This experimental field became one of the backbones for modern coaching development.

The Fighting Spirit to fight difficulties is often identified with the type of intelligence Adversity quotient (AQ). Adversity quotient is the individual's intelligence in overcoming any difficulties that arise [4]. Adversity quotient is considered to support the success of students in 
increasing learning achievement including achievement in playing football. In Soltz study, it is known that people who have a high Adversity quotient can motivate themselves, while individuals who resigned and easily give up with circumstances have a tendency to be negative (low Adversity quotient).

Adversity quotient is an ability or toughness intelligence of how well individuals survive the trials experienced and how well individual ability can overcome them [5]. This is also supported by "who explains that Adversity quotient is person's intelligence in overcoming difficulties and survival"[6].

In learning process, students are required to be able to overcome all problems, difficulties and obstacles that arise so that Adversity quotient is considered important to have. Adversity quotient as a person's intelligence in facing difficulties or problems helps to increase self-potential and live a better life. Thus Adversity quotient is considered more able to see from the positive side; more dare to take risks, so that demands and expectation are used as support to improve learning result and achievements. Adversity quotient is also needed to achieve success in life, because someone who has a high Adversity quotient can be successful even though many obstacle facing, they do not immediately give up and do not let the difficulty destroy their dreams. Besides that, Adversity quotient can also be used as a measuring tool to predict who is able to overcome difficulties and who fell. Everyone has great potential to be successful, but few people believe in their potential that they can succeed. People who believe in their potential can work well, calm, and step forward. While a person who doubts his ability will work with low performance. Therefore, in this research, the development of football learning model based on Fighting Spirit by using Adversity quotient (AQ) theory.

\section{METHOD}

This type of research is a development research (research and developmental/R\&D) aimed at obtaining a learning development model based on Fighting Spirit on football in college. Research and development is a type of research that is widely used to solve practical problems in education. This research consists of two stages that are introduction (pre-research) and experimental research. Research subjects in this study are students of Sport Faculty in Padang State University, lecturers of sport faculty in Padang State University, and football expert.

The procedure of developing football learning model based on Fighting Spirit is done by adopting the ADDIE model which consists of five stages: analysis, design, development, implementation, and evaluation. Analyzing the implementation of instructional design

This is a need analysis step toward the use of instructional design for sport. The target of analysis is the lecturer's planning to implement the design. The analysis was done by distributing the questionnaire to the lecturers using Likert Scale 1-5. The result of the questionnaire is used to decide the quality of football learning model used. Based on the data, the need of instructional design for football should be improved by increasing the struggling basis. Designing the learning model for football (design)

Based on item above, the problems are found and they need to be completed, repaired, and developed in order to be used as the base of designing football learning model using struggling basis. Developing football learning model based on struggling basis (development). Based on the draft of learning model, then a learning model for football based on struggling basis is developed. This learning model is tested its internal consistency by the validator (football expert, students and official). Besides, the validator was the FIK lecturers. Finally, the model implementation is experimented. It is done to know the content, appropriateness, and practicality. The instrument used was questionnaire using Likert Scale 1-5.

Implementing the Football learning Model using Struggling Basis In this level, the developed and validatd learning model is implemented in a learning process at FIK UNP. It is done to know the effectiveness toward football learning. The design implementation is done through quasi-experimental design.

Evaluating the Fottball learning model using Struggling Basis In this level, the instructional design is evaluated The development of football learning model using struggling basis uses Research and Development method. The method consists of 10 steps:

Problem Potency; This study began as the potential problem is found. The step to find the problem is by interviewing and distributing questionnaire to the students about the football learning model usually used in football learning process. Collecting information; This step is aimed at designing football learning model using struggling basis. Product Design; This step is aimed at producing instructional design for football using struggling basis baed on the gathered information. Design Validation; The pre-design learning model is validated by the lecturers of FIK UNP. Upgrading Design; The reparation is done based on the result of FGD which results a model. This model is then tested its reliability in the next step. Product trial and error; The reliability of the model is seen through the questionnaire result responded by the sample. The tested one is the layout, the content, and practicability. The trial and error process are:

Implementing the learning model to the students, and then they respond to the questionnaire. Doing reliability test to the expert. Product Revision: The product is revised based on the result of the trial and error test by analyzing the data. Product trial and error; The learning model is then tried again to the research subject. It would be the real learning model. Product Revision; This is the last step to create the football learning model using struggling basis.

Massive production of the product; The step to distribute the instructional design is done this level. The researcher reconstructs the model based on the trial and error result. As known before, the analysis has been done through interviewing, distributing questionnaire, and observing. The Researcher conducts overall analysis to know the level of effectiveness (process and learning result). Based on the reconstruction and analysis result, the 
real football learning model using struggling basis is design.

To measure the feasibility of the model in these study using two data analysis techniques that is by quantitative methodology using rating scale and using qualitative methodology with observational persistence and triangulation.

\section{RESULTS}

Based on the needs analysis results of football learning model development that the student's Fighting Spirit is still relatively low where it can be seen from 50 statements are needed and 13 statements are needed enough. It means that student's Fighting Spirit in football learning is still low. So it takes a learning model that is based on Fighting Spirit to improve the spirit and the potential that exist within the students because if the Fighting Spirit is high then the football learning results will reach the desired expectations.

Based on the results of this study, it is known that during this time students have low Fighting Spirit in following the football learning. Especially in some aspects, such as the ability to avoid failure, never give up, the ability to predict success. Responses to adversity, persistence, desperate survival, response to adversity as a challenge to be faced, making difficult as an opportunity to achieve success, positive responses to difficulties encountered, building a vision of the future, positive anticipation and expectation of self-esteem, develop selfbeliefs, motivate actions to achieve goals, predict successes to achieves, explain causes of failure, do everything possible to achieve goals, respond to adversity as permanent, think that failure can be prevented, think that everything can be change, can be smarter, faster, better faced with problems, more positive self-esteem, lifebuilding about beliefs about events, composing and achieving important goals in life. Belief in self ability to achieve a certain goal, able to rise from adversity, to perceive difficulties as common, to seek a way out of curiosity, to have personal responsibility for the results, to have personal responsibility for the cause of adversity, action to be taken to rise from difficulties, tends to perceive the difficulty as coming from outside, placing its own role in a right place, and assess the role and learn from behavior.

Those aspects are an aspect of difficulty that students often encounter, but many students choose to avoid and withdraw from adversity because of the low endurance and fighting they have. This category belongs to the Quitter type or surrender. This category tends to always choose a flatter and easier path. They generally work just to live, spirit at work is minimal, do not dare to take risks, and tend not to be creative. Generally do not have a clear vision and low commitment when faced with challenges. This is as described by that "Quitter, those who quit are someone who chooses to get out, avoid obligations, back off and quit when facing difficulties" [6]. Quitters (people who quit), this type of people stop in the middle of climbing process, desperate, give up. In relation to football learning we can categorize students who only accept the learning or task assignments given by lecturers and do it with low motivation. In other words this type of student has the ability to face the pressure of low learning burden.

In facing difficulties required the endurance so as to make difficult as challenge and opportunity. The ability to fight or can also be called the Fighting Spirit is the ability to maintain or achieve something done diligently. Fighting Spirit is the ability to deal with difficulty or resistance to stressful situations [8]. "Problem-solving abilities or endurance in facing problems and risk-taking courage is some factors that influence success" [8]. Someone who has a strong endurance to assess the pressure, competition, the unexpected, even the threat as a temporary thing, so that persist and have hope. This attitude leads someone to devote all the abilities, the potential for the problem immediately resolved. On the contrary, individuals who have low endurance will response to adversity as being permanent, unchangeable resulting in helplessness.

Low student's Fighting Spirit in facing difficulties caused by many factors, among others according because of low motivation in achievement. While the factors affected Fighting Spirit are competitiveness, productivity, motivation, risk taking, endurance, and learning. Based on the results of research obtained, generally low student Fighting Spirit is more due to low motivation, either to compete, survive or to take risks. This is because the use of learning models that are used less effective and unattractive, and more focused on the technical and physical aspects, so that sometimes make students become saturated and bored. So the habit should be changed in order that students have the spirit to respond to difficulties because it can be change.

Therefore, one of the ways in changing the spirit of students in football learning so that the results obtained according to expectations is by using a learning model based on Fighting Spirit. This is because it can increase the spirit of students in responding to difficulties.

From the result of model validation in terms of supporting theories, the structure of learning model football based on Fighting Spirit, and desired learning results are quite good. As well as practically test of learning model seen from the clarity instruction aspects of the use of model, competency achievement, and learning objectives, student's response, difficulty level in implementing and sufficiency of time. Thus, the learning model of football based on Fighting Spirit is expected to be used at the implantation stage to improve learning RESULTS and also student achievement in football.

\section{CONCLUSION}

Based on the results of research learning models development based on the Fighting Spirit need to be developed, because an activity can be successful with high Fighting Spirit. Football learning model based on Fighting Spirit can improve football courses and generally on football training. Football learning development research based on Fighting Spirit is still in the planning and has not arrived at the model testing process. 


\section{REFERENCES}

[1] Herwin, "Latihan Fisik Untuk Usia Muda," FIK UNY; J. UNY. Vol. 1. No. 2, pp 74-85. March 2006."

[2] Weinberg, R. S. \& Gould, D, "Foundations of Sport and Exercise Psychology," Champain IL; Human Kinetics. 1995

[3] Wann, D.J, "Sport Psychology,” New Jersey; Upper Saddle River. 1997.

[4] Hans, Jen z A, "Strategi Pengembangan Diri," Jakarta; Personal Development Training, pp, 86-98. 2006.
[5] Wangsadinata, Wiratman dan G. Suprayitno, Roosseno, "Jembatan dan Menjebatani," Jakarta; Yayasan Obor Indonesia. 2008.

[6] Agustian, Ary Ginanjar, "Rahasia Sukses Membangun Kecerdasan Emosdan Spiritual ESQ: Emotional Quotient Berdasarkan Enam Rukun Iman dan Lima Rukun Islam," Jakarta; Arga. 2001.

[7] Mulyadi \& Mufita, "Pengaruh AQ dan EQ terhadap Kecemasan Persaingan Kerja. Psikoislamika," J. Psikologi dan Keislaman vol 3. No.1, pp, 101-107. Jan. 2006.

[8] Leman, "The Best of Chinese Life Philosophies" Jakarta; Gramedia Pustaka Utama. 2007. 